Discussion Paper No. 04-52

\title{
The Effect of ILO Minimum Age Conventions on Child Labour and School Attendance
}

Bernhard Boockmann

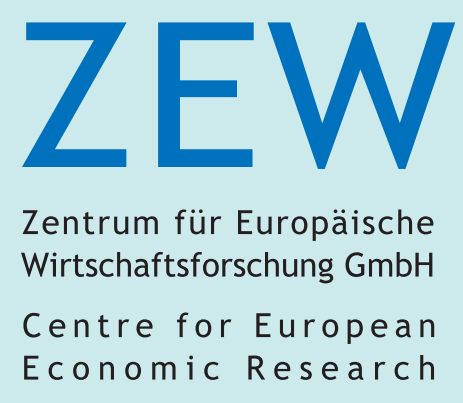


Discussion Paper No. 04-52

\title{
The Effect of ILO Minimum Age Conventions on Child Labour and School Attendance
}

\author{
Bernhard Boockmann
}

Download this ZEW Discussion Paper from our ftp server:

ftp://ftp.zew.de/pub/zew-docs/dp/dp0452.pdf

Die Discussion Papers dienen einer möglichst schnellen Verbreitung von neueren Forschungsarbeiten des ZEW. Die Beiträge liegen in alleiniger Verantwortung der Autoren und stellen nicht notwendigerweise die Meinung des ZEW dar.

Discussion Papers are intended to make results of ZEW research promptly available to other economists in order to encourage discussion and suggestions for revisions. The authors are solely responsible for the contents which do not necessarily represent the opinion of the ZEW. 


\section{Non-technical summary}

Child labour has long been one of the core concerns of the International Labour O rganization (ILO). Since 1919, the year of the ILO's foundation, many international labour standards have been adopted in this field. In this paper, the focus is on ILO conventions as the most legally binding form of standards. If ratified by member states, they must be implemented into national legislation and applied to labour markets.

The effect of the ratification of ILO conventions on economic outcomes is a disputed topic in the literature. In this paper, two different approaches to estimating the effect of ILO conventions on child labour are used. In the first part of the paper, aggregate figures of children's labour force participation and school enrolment are compared between countries having and not having ratified ILO child labour conventions. The sample consists of over 100 developing countries and the indicators are collected for the year 1990. In the second part of the paper, individual-level data of schooling enrolment from a number of developing countries are used to estimate the impact of ratification of one particular convention (Convention No. 138) on schooling enrolment. A difference-in-difference (or natural experiment) methodology is used comparing schooling enrolment of two adjacent age groups covered and not covered by this convention.

In neither parts of the paper, convincing evidence for the effect of ratification of ILO child labour standards on under-age labour force participation or school attendance is detected. By the year 1990, countries under an international legal obligation to enforce minimum age laws had no better performance in terms of child labour and school enrolment than countries not bound by this obligation. A caveat for this part of the investigation refers to data quality. Data may be subject to severe measurement problems. However, using two different indicators relating to labour force participation and enrolment in schooling, the picture was found to be consistent.

Since aggregate data may be too coarse to reflect the true impact of ratification, the second half of the paper uses individual-level data. Presently, there are no comparative surveys on child labour force participation for a sufficiently large number of countries. Therefore, school attendance is used as 
an indirect outcome measure. In one part of the analysis, school attendance of 17 countries from Sub-Saharan Africa is compared between ratifying and nonratifying countries. The results do not offer evidence for the presence of an effect of ratification for these countries. Another part is concerned with school attendance before and after ratification in four developing countries. A significant effect is found in only one of them (Nepal). In this country, however, other policies had been in place that may have influenced school attendance in the age groups covered and not covered on which the natural experiment is based.

It is important to note that this study falls short of a full evaluation of the ILO's activities in this field. In particular, the effects of the ILO's International Programme on the Elimination of Child Labour (IPEC) are not the subject of this study. By looking at the effect of ratification, this paper concentrates on the evaluation of more 'traditional' ILO policies. 


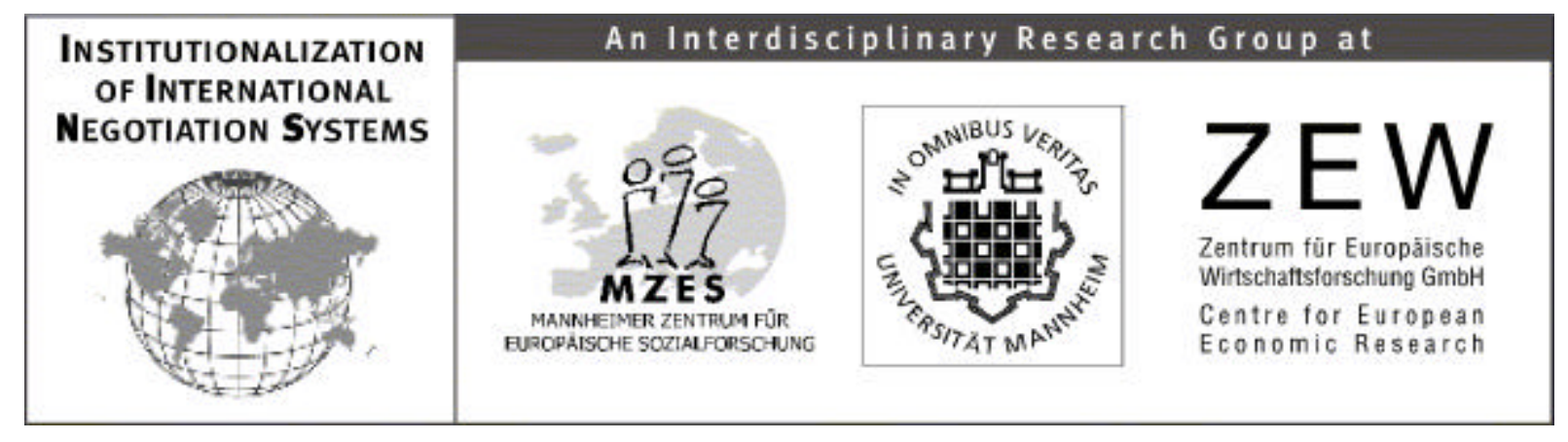

\title{
The effect of ILO minimum age conventions on child labour and school attendance
}

\author{
B ernhard B oock mann \\ Centre for European Economic Research (ZEW) \\ P.O. Box 103443 \\ D-68034 Mannheim \\ Tel. +621 / 1235-156 \\ Fax +621/ 1235-225 \\ E-mail: boockmann@ zew.de
}

IINS Research Paper No. 17

IINS ist eine von der Deutschen Forschungsgemeinschaft finanzierte Forschergruppe. The research group IINS is financed by the Deutsche Forschungsgemeinschaft (DFG).

Projektleiter / Project Directors:

Prof. Dr. Christoph Böhringer, Prof. Dr. Beate Kohler-Koch, Prof. Dr. Franz-Urban Pappi, Prof. Dr. Eibe Riedel, Dr. Paul Thurner, Prof. Dr. Roland Vaubel 


\title{
The effect of ILO minimum age conventions on child labour and school attendance
}

\begin{abstract}
Child labour has always been one of the core concerns of the International Labour Organisation (ILO). In this paper, we investigate whether ILO conventions have contributed to reducing the scale of the problem. We use two approaches to answering the question. Evidence based on country-level data shows that, by 1990, countries having ratified ILO conventions were in no different position concerning child labour than nonratifying states. Using individual-level data on school attendance from the 1990s, there is little evidence for an increase in school attendance for children protected by ILO convention No. 138 as compared to unprotected children.
\end{abstract}

JEL-Classification: J210, J820, 0190

Key Words: Child labour, school attendance, international labour standards, ILO.

Acknowledgement: Earlier versions of the paper have been presented at the ZEW and the Verein für Socialpolitik in Zürich, Switzerland. I wish to thank seminar participants, as well as Bernd Fitzenberger, Charlotte Lauer and Friedhelm Pfeiffer, for helpful comments and Moritz Kuhn, Benjamin O hm and Christoph Junkert for competent research assistance. I am grateful to ORC Macro International Inc. for the opportunity to work with the DHS data. This research was financially supported by the Deutsche Forschungsgemeinschaft (DFG) in the framework of the research group 'Institutionalization of International Negotiation Systems'. 


\section{Introduction}

Child labour has long been one of the core concerns of the International Labour Organization (ILO). The first convention in this field dates from 1919, the year of the ILO's foundation. Since then, many additional legal instruments have been adopted. Conventions are the most legally binding instruments available to the ILO. If ratified by member states, they must be implemented into national legislation and applied to labour markets. At any given time and for any given ILO convention, there will be ratifiers and nonratifiers. The interest of this paper is in evaluating the causal effect of ratification on several outcome variables related to child labour.

Apart from conventions, the ILO adopts labour standards in the form of recommendations which, however, cannot be ratified. Since we are interested in the affect of ratification, recommendations are not considered in this paper. Clearly, there may be other ways apart from ratification how labour standards can affect labour market outcomes. For instance, conventions and recommendations could act as model legislation, transferring knowledge about best practices (Swepston, 1982). They could be used as benchmarks, facilitating comparisons between the current legal situation and internationally recognised standards. However, the centrepiece of ILO standard-setting has always been the adoption of legally binding standards, because it was believed that countries acting without the constraints created by legal obligations would opt for lower standards, putting those with more stringent labour regulation at a competitive disadvantage. ${ }^{1}$

The effect of the ratification of ILO conventions on economic outcomes is a disputed topic in the literature. Some authors raise doubt concerning the ILO's effectiveness, because it has no sanctions at its disposal to safeguard compliance with the standards. ${ }^{2}$ Another drawback is seen in the fact that ratification is voluntary. If conventions are ratified only by countries

\footnotetext{
${ }^{1}$ The preamble to the Constitution of the ILO manifestly expresses this idea: '.. whereas also the failure of any nation to adopt humane conditions of labour is an obstacle in the way of other nations which desire to improve the conditions in their own countries ...'.

${ }^{2}$ See, for instance, Bhagwati (1995: 754).
} 
which already meet the standard given in the convention, then ratification does nothing else but confirm the status quo. ${ }^{3}$

There have been a number of quantitative studies on the impact of ILO conventions recently. Strang and Chang (1993) analyse the impact of ratifying ILO social security conventions on social security expenditures. According to their results, there is a significant effect, but only for industrialised and not for developing countries. Rodrik (1996) and Mah (1997) estimate the effect of the number of conventions ratified on labour costs and export performance. Rodrik (1999) finds that ratification numbers have a positive impact on manufacturing wages in a sample of mainly industrialised countries, but not in a larger sample also comprising many developing countries. Flanagan (2003) presents results from simultaneous estimation of ratification numbers on one hand and labour costs, export performance and foreign direct investment, on the other. He does not find an influence of ratification on child labour. However, this result refers to ratifications of all kinds of standards, not to ratifications of child labour conventions in particular. In a meta-analysis of more than two hundred individual studies, Weichselbaumer and WinterEbmer (2003) find that ratification of ILO Conventions on equal treatment significantly reduces the wage gap between male and female employees.

While there are no quantitative studies of the impact of ILO child labour conventions, there is a large number of studies dealing with the effect of national child labour laws, most of them relating to the adoption of these standards by industrialised countries in the 19th and early 20th centuries (see, for instance, Angrist and Krueger, 1991, Goldin and Katz, 2003, LlerasMuney, 2002, and Margo and Finegan, 1996).

In this paper, two different approaches to estimating the effect of ILO conventions on child labour are used. In the first part of the paper, we compare the aggregate figures of children's labour force participation and school enrolment between countries having and not having ratified ILO conventions. The sample consists of over 100 developing countries and the indicators are collected for the year 1990. The relatively large delay in the data

\footnotetext{
${ }^{3}$ When domestic politics are considered, however, there are a number of reason why there may be pressure from political actors for ratification of conventions specifying standards which have not yet been reached; see Boockmann (2001) and Chau and Kanbur (2002).
} 
is due to availability: the ILO data on participation rates in the age group 10 to 14, the best comparable data available for a large number of developing countries, have been collected in the early 1990s. In the second part of the paper, we use individual-level data of schooling enrolment from a number of developing countries to estimate the impact of ratification on schooling enrolment. We use a difference-in-difference (or natural experiment) methodology comparing schooling enrolment of two adjacent age groups covered and not covered by this convention.

The two approaches complement each other in several respects. While the aggregate approach focuses on the impact of ratification in the long run, the case studies based on individual data also investigate whether there is a measurable impact within several years from the date of ratification. While the first half estimates the impact of ratification both on enrolment and labour force participation, the second half of the paper is concerned with schooling enrolment only but uses more accurate data. And while the aggregate measures do not fully correspond to the age bounds specified in the conventions, it is possible to draw a clear line between protected and nonprotected children using the disaggregate data.

It is important to note that this study falls short of a full evaluation of the ILO's activities in this field. In particular, the effects of the ILO's International Programme on the Elimination of Child Labour (IPEC) are not the subject of this study. By looking at the effect of ratification, this paper concentrates on the evaluation of more 'traditional' ILO policies.

\section{ILO conventions on minimum age}

Child labour has been a subject of standard-setting for the ILO ever since its foundation in 1919. The conventions adopted over the years deal with a diversity of subjects:

- the setting of a minimum age for admission to employment or work (C5, C10, C33, C59, C60, C123, C138);

- the prohibition of night work by young persons (C6, C79, C90);

- the requirement for medical examinations (C77, C78, C124);

- the prohibition of the worst forms of child labour (C182). 
In the following, we are concerned with minimum age conventions only. Table 1 lists all of these conventions except those relating exclusively to the maritime sector, which form a separate body of standards, and explains their main provisions.

\section{table 1 here}

The table shows that ILO conventions are building up on one another, becoming gradually more stringent over time. Moreover, they are increasing in complexity. While the early conventions consist of only three or four articles on substantive provisions, Convention No. 138 contains ten articles with detailed requirements. The increase in complexity is partly due to a greater degree of flexibility of Convention No. 138, which offers member states to subscribe to initially less demanding standards. By contrast, the earlier conventions contain universal standards. While the early conventions are still formally open to ratification, the ILO does not encourage their ratification any longer. To facilitate the operation of the ILO's monitoring system, member states often denounce the 'predecessor' convention when ratifying a revising convention. For instance, as of spring 2004, 72 countries have ratified Convention No. 5 , but 59 have denounced it in the context of the ratification of revising conventions.

ILO child labour conventions can be distinguished according to the scope of application. The earlier conventions all related to particular sectors or activities (such as agriculture, industry, non-industrial employment, and underground work). With the adoption of Convention No. 138, minimum age standards were collected into a common framework for all sectors, maintaining, however, some of the inter-sectoral differentiation contained in the earlier conventions.

The ratification record by 1990, the time of observation in the first half of this paper, shows a diverse picture. ${ }^{4}$ With 69 ratifications, Convention No. 5 had received a relatively high number of ratifications (the average of all conventions adopted prior to 1945 being 36). Convention No. 10 had been ratified by 51 states. Among these, however, were only 28 developing

\footnotetext{
${ }^{4}$ Ratification numbers and dates can be found on the ILO web site, www.ilo.org.
} 
countries. The ratification record for Convention No. 138 had also been somewhat disappointing from the ILO's point of view by 1990. In a report to the International Labour Conference (ILO 1998), the International Labour Office notes that only 21 developing countries had ratified Convention No. 138, none of them in Asia where the main problems were found (p. 22). It states that the complexity of the text of the Convention and the difficulty of applying it may have been an obstacle to ratification.

During the 1990s, major changes have been made to the ILO child labour regime. These culminated in the 'Declaration on Fundamental Principles and Rights at Work' of 1998 and the adoption of Convention No. 182 on the worst forms of child labour in 1999. Initiated by this policy change, the ratification of child labour conventions has picked up dramatically over the last couple of years. Up to June 2004, Convention Nos. 138 and 182 have been ratified by a total of 134 and 150 member states, respectively.

Since the number of ratifications of the conventions concerning nonindustrial employment is not sufficiently large to conduct statistical analysis, we only look at the ratification of conventions relating to industry and agriculture. Furthermore, we do not analyse the effect of ratification of Convention No. 182, because data on the relevant outcome variables is not available. The scope of the study is limited to developing countries.

\section{Economic analysis of child labour legislation}

Do minimum age legislation and, in particular, international standards requiring such legislation, reduce child labour? Economists have discussed this question mostly in the broader context of whether there is a market failure case for government intervention to restrict under-age employment (see, for instance, Baland and Robinson, 2000; Basu and Van, 1998; Dessy, 2000; Dessy and Palage, 2001; Ranjan, 1999, 2001). Several of these papers explicitly consider the effect of either a total ban or a marginal ban (i.e., a cap on the number of hours worked) on child labour as a second-best policy, typically assuming that the ban can be enforced economy-wide. Even in the

\footnotetext{
${ }^{5}$ Other contributions to the debate adopt a non-consequentionalist normative perspective, arguing that child labour violates a universal human right (G rootaert and Kanbur, 1995).
} 
more realistic case where penalties for child labour are not infinite, minimum age legislation exerts a negative effect on the incentive to use child labour. If employing children carries a penalty, or if employers have to pay bribes to the labour inspectors if using child labour, employers' demand for child labour decreases, because economic costs of employment rise. If supply remains unchanged, child labour is reduced.

O ne argument why legislation may fail to achieve the object of reducing child labour is that it often applies only to certain activities. Even if legislation covers the whole economy, it may not be enforced in parts of it, such as in home production, parts of agriculture and fishery and, ultimately, in illegal employment activities. In the framework of an analytical model, Basu and Van (1998) show that if legislation applies only to certain sectors, a partial ban may not reduce aggregate child labour force participation. However, it lowers children's wages, since it leads to excess supply in the sector not enforcing the ban. The effect on the welfare of families targeted by the measure could, therefore, well turn out to be negative.

There is an additional negative effect on wages if the sector where the ban is in force (say, industry) is more productive and pays higher wages than the uncovered sector (say, agriculture). In this case, there will be an inflow of child labour into low-productivity employment as a consequence of introducing legislation. A ban on child labour may, therefore, have undesirable effects on the structure of child work, in the extreme fostering illegal and hidden forms of employment (Baland and Robinson, 2000, footnote 20).

If child wages are reduced as a consequence of legislation, this leads to a decrease in the wealth of families with working children unless this effect is more than offset by the rise in adults' wages due to the overall reduction of labour supply. If, as is widely suggested (LO, 2002), child labour depends negatively on family wealth, the consequence may be that even more children are sent to work due to a negative income effect. ${ }^{6}$ Thus, legislation which does not apply universally may turn out to be counter-productive: a country

\footnotetext{
${ }^{6}$ Surveying the available empirical literature, Grootaert and Kanbur (1995) report only positive estimates for the own-wage elasticity of child labour. However, these estimates are likely to apply only to the formal sector of the economy. Bhalotra (2000) finds a negative own-wage elasticity for Indian boys, but not for girls.
} 
that bans child labour in some sectors of employment but not in others may not decrease, and in the extreme even increase, the share of children in the working population. ${ }^{7}$

Apart from problems with legislation in general, the effect of ratification could be hampered by the lack of implementation by member states. The ILO monitors the implementation of its conventions by a complex system of evaluation (see Swepston, 1997). The Committee of Experts concerning the Application of Conventions and Recommendations, the CEACR, issues 'observations' in cases of severe and lasting cases of non-compliance with a ratified convention. During the 1980s, the number of 'observations' on child labour conventions was 34, counting only once those 'observations' that had been made repeatedly. A problem is that 'observations' arise from the comparison of the legal situation with the text of the conventions. If national laws are not enforced, the CEACR is much less likely to notice noncompliance. 'Observations' should thus be seen as measures of states' compliance with their duties as legislators, rather than as indicators for the enforcement of domestic legislation.

To conclude, while ILO minimum age standards could be effective means to reduce child labour due to a decrease in child labour demand, they might fail to produce the desired effect on several counts. While governments' failure to implement conventions into national legislation or the low level of domestic enforcement in general are often cited as the main problems for the effectiveness of ILO standards, the fact that some minimum age conventions concern only particular sectors of the economy may be even more damaging for their impact on children's aggregate labour force participation. Moreover, even if a country has signed up to conventions concerning all sectors, the lack of enforcement in specific areas may cause the effect of standards to evaporate. Other policies, such as creating incentives for school attendance, increasing families' wealth by transfer programmes, or tackling the market failure problem more directly, e.g. by removing credit market constraints, may be more appropriate instruments in this case.

\footnotetext{
${ }^{7}$ Similarly, if the economic burden of penalties or bribes paid to labour inspectors is borne by families with working children, child labour could increase due to a negative wealth effect.
} 


\section{Aggregate data on child labour and empirical methodology}

D espite the attention the subject has found in recent years, there is a scarcity of data on child labour comparable both over countries and over time. In the following two sections, we use two data sources that contain information on indicators closely related to the problem, although they do not match exactly the definition of child labour from the ILO conventions. The first is the ILO data set on the economically active population. This data is available by age groups and contains the age group 10 to 14 as the youngest stratum. The second is the UNESCO data on schooling enrolment.8

The reason for using two different indicators is that these two measures complement each other and give some impression of the robustness of the results. Both cover only some aspects of child labour. Since the ILO data is limited to the age group 10 to 14, it gives no information about the even more problematic phenomenon of child labour below age 10. Conversely, employment of 14 year olds does not contradict some of the ILO conventions. Concerning the usefulness of the UNESCO data, only some minimum age conventions, such as Conventions No. 10 and 138, address schooling enrolment directly. Our justification for using the data is that child labour and non-participation in basic schooling are often two sides of the same coin. While there is controversy in the empirical literature about the effect of child labour on educational non-attainment (Baland and Robinson, 2000), studies based on micro-data typically find a strong link between these phenomena. $^{9}$

The UNESCO data are derived from questionnaires sent to national education authorities. National statistical or educational publications are used

\footnotetext{
${ }^{8}$ An alternative data source for enrolment in education is the Demographic and Health Surveys funded by the U.S. Agency for International D evelopment (USAID), which applies the same survey instruments for about 50 countries, and is used in the second part of this paper. Although aggregates based on these data would certainly be more exact than the UNESCO data, we choose the latter because the number of countries sampled is much higher.

${ }^{9}$ For instance, Psacharopoulos (1997) finds that working children have significantly fewer years of schooling in Bolivia and Venezuela. For the combination of work and school, see Anker (2000: 272ff.). Mehran (2000) provides an attempt to cross-validate the ILO and UNESCO data.
} 
to cross-reference figures. ${ }^{10}$ The data used refer to gross enrolment ratios in primary education. The numerator of this ratio includes the number of children enrolled in primary education. The denominator contains the population age group corresponding to official primary school age. ${ }^{11}$ Since children may remain in primary education beyond official age, gross enrolment ratios may exceed 100 per cent.

The ILO data is based on population censuses and sample surveys collected by national authorities. ${ }^{12}$ Various adjustments to the raw data are necessary to ensure that the definition of the economically active population is consistent over different countries. The concept of measurement was adopted by the International Conference of Labour Statisticians in 1982. It contains full-time as well as part-time employees and includes individuals otherwise engaged in education, unpaid family work, the armed forces, and the unemployed.

A problem with both series is that they tend to be extrapolated from only a few points of time. As a result, the degree of autocorrelation in the series is high. Indeed, even taking five-year or ten-year intervals of the data, we obtained a coefficient on the lagged dependent variable not significantly different from unity in dynamic fixed-effects estimation both for activity rates and for enrolment. ${ }^{13}$ The usual cure for this problem, first-differencing the data over intervals of five or ten years, is not viable because the ratio from 'signal' to 'noise' is lowered so that no statistical correlations remain significant.

Therefore, analysis is based on the cross-sectional variation in the data for the year 1990, the most recent year for which ILO data are available. Alternatively, we present results based on 'long differences' in child labour and enrolment over the period from 1970 to 1990. The data set comprises

\footnotetext{
${ }^{10}$ More information on the generation of the data can be found on the UNESCO website, www.uis.unesco.org.

${ }^{11}$ In the overwhelming number of cases age 11 or 12 in developing countries. Since the variance of official age for primary schooling appears to be reasonably low, we do not make corrections for it in our further analysis.

${ }^{12}$ A detailed description of the construction of the data is given by ILO (n.d.).

${ }^{13}$ Period dummies were included in these estimations.
} 
developing countries only. ${ }^{14}$ Figure 1 shows the distribution of activity rates and enrolment ratios for male and female children in the sample. The figure shows a wide variation of outcomes. As expected, enrolment ratios tend to be higher for boys than for girls. At the same time, male activity rates are also higher than the corresponding measure for females. This pattern is explained by the higher percentage of girls engaged in activities at home and neither working nor attending school.

\section{figure 1 here}

In the following, we present comparisons of mean activity and enrolment levels, distinguishing between countries which have and have not ratified the conventions under investigation. Furthermore, we examine whether the changes in these variables between the years 1970 and 1990 can be attributed to ratification. Results from OLS estimation of activity and enrolment on ratification dummies and a number of other potential determinants of child labour led to the same conclusions. They are not reported but available on request from the author. ${ }^{15}$

It is important to understand which groups of countries one is comparing, since there are several conventions which could influence activity rates and enrolment. Comparing child activity rates among the ratifiers of a low-standard convention (such as Convention No. 5) with a comparison group of non-ratifiers of that convention may be meaningless, because some of the countries in the comparison group may have ratified another, more

\footnotetext{
${ }^{14}$ The data excludes the founding members of the OECD, together with Finland, New Zealand and Japan, but includes Turkey. Former COMECON member countries are also dropped from the data.

${ }^{15}$ To account for possible endogeneity of ratification status, we also estimated all equations by instrumental variables. Following Weichselbaumer and Winter-Ebmer (2003), we used two different instruments for the ratification of child labour conventions: first, the total number of ratifications on all ILO conventions reported for the individual country, and, second, the number of ratifications of the individual convention within a 'peer group' of geographically neighbouring countries. The year of ILO membership was used as an additional instrument. These estimations yielded similar results as compared to comparisons of means and OLS.
} 
advanced convention. O ur strategy is to perform sets of binary comparisons for countries which belong to a certain 'ratification group' with countries which have not ratified any convention. Ratification groups are defined, first, along the scope of the conventions, i.e., ratifications of conventions relating to industry and agriculture are treated separately. Second, ratification groups are defined according to the most advanced of the conventions a country has ratified. ${ }^{16}$ This leads to the following ratification groups:

- countries having ratified no minimum age conventions;

- countries having ratified Convention No. 5 but no other convention;

- countries having ratified Convention No. 59 and possibly Convention No. 5 ;

- countries having ratified Convention No. 138 and possibly Convention No. 5 or Convention No. 59;

- countries having ratified Convention No. 10 but no other convention.

For the 'long difference' effects, we consider the ratification of any ILO minimum age convention, since there are too few ratifications for any single convention over the interval from 1970 to 1990.

\section{Results from aggregate data}

Table 2 displays the means for both variables of interest for ratification groups and t-statistics for the significance of the difference across these groups. Since enrolment ratios, and even more so activity rates, do not seem to be normally distributed, we display the p-levels of non-parametric MannWhitney tests for differences in the distributions in addition to conventional tstatistics. The Mann-Whitney test is calculated using the ranks rather than the values of the variables and does not depend on the normality assumption.

\footnotetext{
${ }^{16}$ The sequential nature of ratification of different standards makes the interpretation of the results difficult. As a consequence of the construction of comparison groups, countries which subsequently ratified more advanced conventions are missing from the group of ratifiers of an early convention. If countries having ratified an early convention but having failed to ratify more advanced conventions are a negative selection from the group of original ratifiers, there is a downwards bias in the coefficient of ratification for the early convention. This problem cannot be avoided since it is not possible to separately identify selection into the different ratification groups.
} 
Separate tests are performed for male and female children, since male and female child labour may be affected differently by minimum age legislation. The first three lines contain tests for countries having or not having ratified Conventions Nos. 5, 59 and 138. The fourth line refers to the ratification of a convention relating to agriculture only, i.e. Convention No. 10. Since the scope of application is different for this convention, the group of non-ratifiers used as a comparison group includes countries having ratified Conventions Nos. 5 or 59 but does not include ratifiers of Convention No. 138, which also covers the agricultural sector.

As mentioned in section 2, a reason why conventions may lack effectiveness is incomplete compliance by member states. If member states regularly fail to introduce the legislative measures required by conventions, one should not expect ILO conventions to contribute to the reduction of child labour. To account for non-compliance, the 'observations' issued by the ILO's expert committee (CEACR) in cases of non-compliance are used. Ratification dummies are set from one to zero for countries having received an 'observation' by the CEACR on the same convention during the 1980s. Results are contained in the second and fourth columns of table 2 (activity rates II and enrolment II), while the first and third columns contain results using unadjusted ratification numbers.

The table shows that the hypotheses that the 1990 levels of activity rates and enrolment ratios are the same for ratifying and non-ratifying countries cannot be rejected at the five percent level for any of the ILO conventions. From the first line of the table, it appears that countries having ratified Convention No. 5 may even perform even worse than non-ratifiers with regard to activity rates and enrolment, with activity rates being six to seven percentage points higher and enrolment ratios being six to seven percentage points lower. However, only for one of the variables used (activity rate II) do the tests reject equality in means or distributions, and they do so only at the ten per cent level. This might indicate that ratification is even counter-productive. However, there is also the problem of negative selection bias as mentioned in footnote 16. Furthermore, the effect disappears in the 
OLS estimations (not reported). Regarding the other conventions apart from Convention No. 5, ratifiers tend to perform slightly better than non-ratifiers, but the differences are not significant.

The last rows of the table compare the differences in school enrolment and activity rates over the 20-year interval from 1970 to 1990 according to whether the country had ratified any convention during this interval. Results were substantially unchanged when only ratifications of Convention No. 138 were considered (19 ratifications during this interval). The data show that there are no differences in the change of activity rates for boys. For girls, however, ratifying states exhibit smaller reductions than for non-ratifying states; the coefficient is significant at the five per cent level. Again, the significance of the effect disappears when control variables are added. No significant differences are found for school enrolment. No countries in the group of ratifiers received an 'observation' during the 1980s. Hence, there is no difference in the results according to whether compliance is accounted for in the measurement of ratification status.

\section{An approach using individual-level data}

In the following two sections, we investigate whether ratification of Convention No. 138 has contributed to increasing school attendance of children protected by the convention as opposed to children not protected. The investigation is based on data from the D emographic and Health Surveys (DHS), a project initiated by the U.S. Agency for International D evelopment (USAID) to provide data and analysis on the population, health, and nutrition of women and children in developing countries. DHS Surveys are nationallyrepresentative household surveys with relatively large sample sizes (usually between 5,000 and 30,000 households). For a number of countries, repeated surveys are also available. There are different series of surveys (D HS I to III, D HS+) using different questionnaires and sample sizes. Surveys are structured into different parts which may not be included in all surveys. Questionnaires are highly standardised across countries participating in the programme. ${ }^{17}$

\footnotetext{
${ }^{17}$ For a history and overview of the surveys, as well as questionnaires and information on survey methods, see www.measuredhs.com and Vaessen, Thiam and Lê(2003).
} 
School enrolment is taken from the household questionnaire. This part of the survey contains a question asking for each member of the household whether the individual is currently attending school. No further specification is given as to which institutions count as 'schools'. The question is not included in the first series of surveys, D HS I, but is available in all subsequent surveys.

To estimate the impact of ratification on school attendance, we use a difference-in-difference procedure based on the fact that Convention No. 138, by specifying an age limit for employment, gives protection to certain age groups only. The task is to identify the additional protection (in addition to other policies possibly in place, such as a national minimum age) ratification provides to targeted children. An effect may be produced by the introduction of new child labour legislation, by the extension of existing legislation to sectors previously uncovered, or by improved enforcement of existing laws if these laws are backed up by an international obligation. As some legislation exists in all countries, the second and third mechanisms are probably more important to this study than the first.

The age limit specified in convention No. 138 is the maximum of official school leaving age and 15 years (whichever is higher), but insufficiently developed countries may deviate from this provision by specifying a general minimum age of 14 years (see table 1). All countries used for our analysis have made use of the latter provision. Hence, children are covered up to their 14th birthday in the countries under observation. If ratification has an effect on school attendance, the difference in enrolment between individuals below 14 years of age and individuals 14 years or above should generally be higher in ratifying states than in non-ratifying states. Specifically, the age groups concerned in the following are children aged 13 and 14 years.

In the first set of estimates, we use data for all countries in Sub-Saharan Africa for which D HS surveys are available, except for South Africa, Namibia and Zimbabwe which are not comparable on the basis of history and income per capita. Furthermore, we except Kenya and Zambia, where a higher age limit in ratifying Convention No. 138 applies than in the other countries so that a comparison would have to be based on a different age group. Two countries (Benin and Burkina Faso) ratified the convention within or close to the observation period, so we cannot treat them either as ratifiers or nonratifiers. There remain 5 countries having ratified Convention No. 138 
(Malawi, Niger, Rwanda, Tanzania, and Togo) and 12 non-ratifiers (Cameroon, CAR, Chad, Cote d'Ivoire, Gabon, Ghana, Guinea, Madagascar, Mali, Mozambique, Nigeria, and Uganda). ${ }^{18}$

A second set of estimates compares school attendance before and after the ratification of Convention No. 138. This procedure requires that at least one DHS II, III or DHS+ survey before the date of ratification and at least one survey after the ratification date is available. Among the about 40 countries for which more than one DHS survey is currently available, there are four countries which fulfil this criterion: Bolivia, Egypt, Nepal, and Tanzania.

Since individuals' ages are recorded in the data, the most direct way to implement the difference-in-difference estimator is to compare school attendance rates between adjacent age groups. Angrist and Krueger (1991) have used this approach to investigate the effect of compulsory schooling laws on school attendance in the US for the years 1960, 1970 and 1980. They find significant effects for the earlier years: in states requiring youths to attend school beyond their 16th birthdays, the difference between attendance rates at 15 and 16 years was significantly lower than in US federal states where youths could legally drop out at 16 .

O ur estimator is similar in spirit to the Angrist-Krueger estimator, with the exception that the comparison group comprises children not protected while, in the Angrist-Krueger case, the comparison group is children always protected. As in the Angrist-Krueger case, there may be a problem of underestimation of the effect if the comparison group of individuals is also influenced by ratification. In particular, one would not expect that children aged 13 at the beginning of the school year immediately drop out of school once they have reached their 14th birthday. Rather, many of them will finish the school year even if, in the absence of protection, they would not have attended school. The longer the time from the beginning of the school year, the more serious is this problem. If this behaviour is present, the difference-

\footnotetext{
${ }^{18}$ See table A2 in the appendix for survey and ratification dates.
} 
in-difference estimates will be too conservative and should be only interpreted as a lower bound for the effect of ratification. ${ }^{19}$

D rawing on Angrist and Krueger (1991), Margo and Finegan (1996) propose a procedure resting on the time of birth within the year to identify the effect of compulsory schooling laws. They are concerned with the effect of compulsory schooling laws requiring children to stay at school up to their 14th birthdays in the US at the start of the 20th century. The particular difficulty in their data is that school attendance at a particular date is not available, but only total months of school attendance in a given census year. Hence, a difference-in-difference estimate cannot be based on current school attendance and current age. But since the exact date of birth is observed in their data, a comparison can be made between an earlier cohort of individuals 14 years at the start of the school year and a later cohort of children whose 14th birthday occurred some time after the start of the school year. In this way, they distinguish between children not protected over the whole school year and children protected over at least a significant part of it. This approach has the advantage that the comparison group does not contain individuals who, despite being not currently under treatment, are still influenced in their decision by a treatment completed at the time of observation.

As the data do not contain the date of birth, Margo and Finegan's estimator cannot be directly implemented. However, the month of observation is available from the data. Based on this information, we define a control group to contain individuals at the age of 14 if they are observed within three months from the start of the school year and youths at the age of 15 if they are observed more than three months after the start of the school year. The idea is that the vast majority of individuals aged 14 at the time of the survey had started the school year at that age if they are observed directly after the start of the school year. Moreover, in cases where the 14th birthday

\footnotetext{
${ }^{19} \mathrm{On}$ the other hand, they may over-estimate the effect of ratification if the ratification follows a decline in child labour due to changes in demand or supply; see Moehling (1999). Moehling proposes to use a DDD (difference-in-difference-in-difference) estimator to reduce this bias. Unfortunately, her approach cannot be sensibly implemented with our data. However, the issue is less pressing in our case, since we do not find significant effects in the first place and, hence, we are more concerned about possible under-estimation than about over-estimation.
} 
occurred briefly after the start of the school year, it is likely that individuals either drop out immediately after turning 14 (since the end of the school year is some time to go) or do not even start the new school year (since the risk of being caught non-attending is small over a brief period of time).

Figure A1 in the appendix gives an example. In the Central African Republic, the school year starts in September, and the field work for the survey was conducted over the period from September 1994 to March 1995. The comparison group includes individuals aged 14 observed from September to November 1994, and individuals aged 15 observed in December 1994 to March 1995. Clearly, this way of proceeding produces control groups that vary in average age across countries due to differences in the date of the survey relative to the start of the school year. Comparing between ratifying and nonratifying states, it is, therefore, important to verify that average age in the control group is similar in both groups.

There are a number of other problems with the difference-in-difference estimator in our context. In particular, countries may have introduced other policies apart from ratification specifically directed towards particular ages. These may be national minimum age policies or educational policies. If children aged 13 are targeted by these policies but children aged 14 are not, it will not be possible to identify the effect of ratification separately from the effect of national policies. How convincing the evidence for an effect of ratification is depends on the absence of these targeted policy measures. Indeed, this is the main reason for looking at the time changes in specific countries. While the effort required to track down all relevant national policies in a cross-section of about 20 countries would be enormous, ${ }^{20}$ it is more feasible to give an account of changes in these policies undertaken within a short period of time. On the other hand, in a sufficiently large sample of countries, national policies may be treated as a part of the residual variance as long as ratification and policies are independent.

\footnotetext{
${ }^{20}$ We did, however, look at the national minimum age. The result is that all ratifying countries of our sample had a national minimum age of 14 . Hence, the lack of a difference in school attendance between ages 13 and 14 cannot be attributed to a national minimum age influencing behaviour in the group of 14 year olds.
} 


\section{Specification and results}

Table 7.4 contains the means of school attendance for the different age groups for the sample of 17 countries from Sub-Saharan Africa. The upper panel presents results with the comparison group of individuals aged 14, while results from the lower panel are for the comparison group constructed in the way described above. ${ }^{21}$ The data are weighted using the survey weighting factors in order to achieve representativeness of the national aggregates. Furthermore, the survey weighting factors are multiplied with country-level weights giving each country equal impact on the results. In a different set of estimations, we weighted the data according to total population, which led to similar results to those presented here. However, these results were more sensitive to the exclusion of particular countries.

\section{table 3 here}

The table shows that ratifiers and non-ratifiers in the sample have similar levels of school attendance. Among those covered by the convention, i.e. the age group of 13 year olds, ratifying countries have, on average, a 3.5 percentage point lower school attendance rate than non-ratifiers. It is tempting to relate this finding to similar results from the aggregate data analysis. However, the temptation should be resisted, since the result is likely to change with respect to changes in the sample. The table also shows that the difference in school attendance between ages 13 and 14 is minor, while attendance levels off substantially after age 14 .

If ratification of Convention No. 138 increases the protection of children covered by the convention, this will show in a significantly positive difference-in-difference effect. The upper DD effect in each half of the table is simply the difference-in-difference in the means displayed in the table, with the p-values taken from regressions and probit estimation with age group, country and interaction dummies. We observe that the estimated DD effects are small in magnitude and, in any case, statistically insignificant, no matter which comparison group is used. If the second approach to defining a

\footnotetext{
${ }^{21}$ Differences for the treatment group between the upper and lower part of the table are due to differences in weighting factors.
} 
comparison group is used, average age in the comparison group is 14.66 for ratifiers and 14.69 for non-ratifiers. Hence, any bias resulting from differences in composition of the comparison groups according to ratification status can only be minimal.

The lower DD effect is from an extended regression with covariates explaining school attendance, since the observed changes may be attributed to other factors apart from ratification. ${ }^{22}$ The D HS household recodes contain a number of variables which can be used to predict school attendance. Apart from age, there is basic information relating to the individual, such as sex and variables indicating whether the individual's father or mother is still alive or whether the individual is a regular member or a child residing only temporarily in the household. There are also a number of characteristics relating to the household or the household head. Among the former, the number of children or youths below 6, below 14 and below 18 years living in the household are used. Furthermore, there is information concerning possession of certain household assets (such as possession of a bicycle, motorcycle or car, the material used for walls and pavements, the type of water supply etc.). Filmer and Pritchett $(1999,2001)$ argue that these asset variables can be aggregated to a measure of permanent income even more accurate than income measures taken directly from survey questions. We follow their procedure and perform a principal components analysis of the asset variables, using the first principal component as an indicator of the household's wealth. A further dummy variable indicates whether the household is situated in a rural or urban area. Finally, we include dummy variables indicating whether the household head is female and whether the household head has completed primary and secondary education, respectively.

For all of these covariates, country-specific coefficients are estimated. Average coefficients and their t-statistics are contained in table A2 in the appendix. To indicate the range of outcomes, the table also contains the minimum and maximum coefficients found in the estimations and the tstatistics of these coefficients. Gender, family wealth and education of household head have pronounced effects on school attendance. The presence

\footnotetext{
${ }^{22}$ For studies on the determinants of child labour other than ILO conventions, see the surveys by Brown et al. (2003) and G rootaert and Kanbur (1995).
} 
of small children in the household has a negative effect on attendance, presumably because parents' attention will be detracted from their school-age children. Conversely, attendance is higher if there are household members between 14 to 18 years of age. Most importantly, the difference-in-difference results shown in table 3 are all insignificant, pointing to the absence of an effect of ratification on school attendance. A sensitivity analysis with respect to changes in the sample was performed by excluding, in turn, each country from the sample. Again, no significant estimates for the difference-indifference effect were obtained in any of the subsamples.

We next discuss difference-in-difference estimates for changes in ratification status over time. These estimates are performed for the control group of 14 year olds only, since differences in survey date would have produced changes in the average age in the control group had the second approach been adopted. Table 4 shows that developments in school attendance have been quite different across the four countries under investigation. Bolivia, Egypt and Nepal managed to increase enrolment ratios by quite substantial amounts. The highest increase is found for Nepal, where attendance among children aged 13 increased by 11 percentage points. With increases of about eight percentage points in Egypt and about five percentage points in Bolivia, changes in these countries are smaller but still a marked change. By contrast, Tanzania experienced a decline in enrolment ratios of four to five percentage points from 1996 to 1999. This suggests that ratification of Convention No. 138 could not prevent the decline in school attendance observed over the period. This decline followed, however, a strong increase in enrolment ratios from 1992 to 1996 in both age categories, but particularly among youths aged 14 years $(+7.8$ percentage point as opposed to +1.6 percentage points for children aged 13).

\section{table 4 here}

Considering the difference-in-difference results based on comparisons of means only, none of the effects are statistically significant at conventional levels. However, the effect measured for Nepal has the expected sign and is large in magnitude: after ratification, school attendance increased by 4.5 percentage points more for children protected by the convention than for 
children not protected. Still, the p-level of the effect is higher than conventionally accepted as a rejection of the null hypothesis of a difference of zero. In the other cases, the difference-in-difference effect is insignificant.

Again, the variance may be reduced by accounting for covariates. Results for probit estimations are contained in table A3. As in the previous estimations, the influences of gender, wealth and education are highly pronounced in the results, although girls have a lower probability of attending schools than boys in Egypt, Nepal and Bolivia but not in Tanzania. The difference-in-difference effect is again completely insignificant in Tanzania, Egypt and Bolivia. The situation is now quite different for Nepal where the difference-in-difference effect is now significant at the five per cent level. These results suggest that school attendance improved for children protected by Convention No. 138 more than among non-protected children. This can be interpreted as the effect of the value added of ratification towards increasing school attendance by lowering child labour.

A possible objection to interpreting these results as evidence for a causal effect of ratification is that other developments, such as educational policies directed at particular ages, may account for the estimated effects. Table A4 provides an overview of national legislation, listing any changes in national minimum age and compulsory schooling laws. Moreover, the World Bank's data base on projects and programmes has been searched in order to account for development programmes possibly affecting the proportion of children in different age groups going to school. The table suggests that substantial measures in this area have been introduced in two countries of the sample. In Egypt, there have indeed been wide-ranging changes to the legal framework concerning children. The statutory minimum age was raised from 12 to 14 years in 1996. Moreover, Egypt made nine years of education compulsory in 1996 (previously, compulsory education had lasted for only eight years). The main impact of the increase in mandatory schooling affects children older than 14, but some children of this age may also be affected. The Basic Education Improvement Project financed by the World Bank and active from 1993 may also have had an influence on enrolment, but increasing enrolment was only one of several objectives of the project.

In Nepal, the Basic and Primary Education Project, financed by the World Bank from 1992, aimed to strengthen the provision of primary 
schooling and to support a range of projects concerning non-formal schooling. Covering all districts in the country, the programme was targeted at poor and socially disadvantaged students in particular. Being focused on primary education, the programme is likely to affect 13 year olds to a greater degree than 14 year olds. Indeed, we find in the data that 62 per cent of all 13 year olds attending school were enrolled in grades 1 to 5 in the base year (1996), while the corresponding number for youths aged 14 years is 44 per cent. Thus, ratification of Convention No. 138 was not the only policy measure in the observation period introduced to reduce child labour and increase school attendance. The evidence does, therefore, not unambiguously point to a positive effect of ratification. However, it may perhaps be read as evidence that there is a joint effect of child labour standards and development policies to increase school attendance.

For the other two countries, no changes in the legal situation of children during the observation period were found. Moreover, while there were several development projects in action during the period (many of them under the roof of the ILO's IPEC programme), there was no nation-wide comprehensive programme aiming at eradicating child labour or raising school attendance. Among the projects of the World Bank, the Bolivian Education Reform Project was not directly aimed at increasing enrolment. Clearly, there may be smaller projects at the regional or sectoral level affecting children at ages 13 or 14 differently having escaped our attention, but these are unlikely to have led to nation-wide changes in age specific enrolment ratios. Bolivia is the only country in the sample found to be in non-compliance with child labour conventions during the observation period. Bolivia repeatedly received 'observations' from the CEACR on Convention No. 5 on the matter of apprenticeship of children 12-14, and an 'observation' in 2003 concerning C138 on the same matter.

A brief summary of the results from the case studies is given in table 5 .

table 5 here 


\section{Conclusions}

Using a diversified empirical strategy, we did not detect any convincing evidence for the effect of ratification of ILO child labour standards on underage labour force participation or school attendance. The first part of the paper has shown that, by the year 1990, countries under an international legal obligation to enforce minimum age laws had no better performance than countries not bound by this obligation. A caveat for this part of the investigation refers to data quality. Data may be subject to severe measurement problems. However, using two different indicators relating to labour force participation and enrolment in schooling, the picture was found to be consistent.

Since aggregate data may be too coarse to reflect the true impact of ratification, the second half of the paper used individual-level data. Presently, there are no comparative surveys on child labour force participation for a sufficiently large number of countries. Therefore, we used school attendance as an indirect outcome measure. Again, the results did not offer convincing evidence for the presence of an effect of ratification for the countries under investigation. The caveat for this part of the study relates to the applicability of methods. If minimum age conventions have an effect outside the age group to which they apply, we are likely to underestimate the effect. Moreover, if there are policy programmes relating to particular age groups, the effect of ratification cannot be identified separately from them. However, not all of the case studies plausibly suffer from these shortcomings.

The view that ratification may have little more than symbolic meaning is consistent with our results. But it would be equally consistent with our results that ILO child labour conventions are effective informally as model legislation guiding states in the design of labour law, even if they are not ratified. ${ }^{23}$ In this case, it would not be the international standards as such which fail to have an impact. Rather, it is only the character of the conventions as legal obligations which does not provide an additional incentive to keep to the ILO's standards. Evaluating the 'informal' route by which ILO standards may be included in national politics clearly would be

${ }^{23}$ See ILO (1976: 30ff.) for a discussion of the importance of ratification for the effectiveness of ILO standards. 
much more difficult than comparing the situation in ratifying and nonratifying states. In any case, a policy conclusion is that ratification numbers should not be used as indicators of the actual situation concerning child labour.

A third interpretation of the results could be that the fault does not lie just with international standards but with the legislative approach to child labour in general. Thus, even if ILO standards would be fully complied with, an increase in compliance might have no effect on the amount of child labour, and may actually be welfare-reducing for the individuals affected by it. More appropriate policies may be to increase technical cooperation in order to strengthen education systems and target poverty. Evaluating the effectiveness of national minimum age laws is beyond the scope of this paper. However, in the case of Egypt, the increase in the minimum age to 14 years did not appear to have a positive effect on school attendance in this age group. This casts doubt on the usefulness of a legislative strategy in general.

D uring the last decade, the ILO has made a number of changes to its policies concerning child labour. In particular, the ILO has strengthened nonlegislative policies to eradicate child labour. The most important instrument in this context is the 'International Programme on the Elimination of Child Labour (IPEC)', which covers data collection, organises research and funds technical cooperation projects. In the future, new and better data should become available to evaluate the success of this change in strategy. 


\section{References}

Angrist, J.D .; A.B. Krueger (1991), D oes compulsory school attendance affect schooling and earnings?, Q uarterly Journal of E conomics, 106, 979-1014.

Anker, R. (2000), The economics of child labour: A framework for measurement, International L abour R eview, 139, 257-280.

Baland, J.-M.; J.A. Robinson (2000), Is child labor inefficient?, Journal of Political E conomy, 108, 663-79.

Basu, K.; P.H. Van (1998), The economics of child labor, A merican E conomic R eview, 88, 412-427.

Bhagwati, J. (1995), Trade liberalisation and 'fair trade' demands: Addressing the environmental and labour standards issue, W orld E conomy, 18, 745-759.

Bhalotra, S. (2000), Is child work necessary?, DED PS Discussion Paper No. 26, London School of Economics and Political Science.

Boockmann, B. (2001), The ratification of ILO conventions: A hazard rate analysis, E conomics and Politics, 13, 281-309.

Chau, N.H.; R. Kanbur (2002), The adoption of international labour standards conventions: Who, when and why, in: Collins, S.M.; D. Rodrik (eds.), Brook ings Trade F orum 2001.

Dessy, S.E. (2000), A defense of compulsive measures against child labor, Journal of D evelopment E conomics, 62, 261-275.

D essy, S.E; S. Pallage (2001), Child labor and coordination failures, Journal of D evelopment E conomics, 65, 469-476.

Flanagan, R.J. (2003), Labor standards and international competitive advantage, in: R.J. Flanagan; W.B. Gould (eds.), International Labor Standards: G lobalization, Trade, and Public Policy, Stanford University Press.

Filmer, D .; L. Pritchett (1999), The effect of household wealth on educational attainment: Evidence from 35 countries, Population and D evelopment Review, 25, 85-120.

Filmer, D .; L. Pritchett (2001), Estimating wealth effects without expenditure data - or tears: An application to educational enrollments in States of India, D emography, 38, 115-132.

Goldin, C. and L. Katz (2003), Mass secondary schooling and the state: the role of state compulsion in the high school movement, NBER Working Paper No. 10075.

Grootaert, C.; R. Kanbur (1995), Child labour: An economic perspective, International L abour Review, 134, 187-203.

ILO (1976), The Impact of International L abour Conventions and Recommendations, G eneva.

ILO (1991), Child labour: Law and practice, C onditions of W ork D igest, vol.10.

ILO (2002), A future without child labour, International Labour Conference, $90^{\text {th }}$ Session, Report I(B).

ILO (n.d.), Estimates and projections of the economically active population 1950-2010, Sources and M ethods, C ompanion to the Y earbook of L abour Statistics. 
Lleras-Muney, A. (2002), Were Compulsory Attendance and Child Labor Laws Effective? An Analysis from 1915 to 1939, Journal of Law and E conomics, 45, 401-435.

Mah, J.S. (1997), Core labour standards and export performance in developing countries, W orld E conomy, 20, 773-785.

Margo, R.A.; T.A. Finegan (1996), Compulsory schooling legislation and school attendance in turn-of-the-century America: A 'Natural Experiment' approach, E conomics L etters, 53, 103-110.

Mehran, F. (2000), ILO labour force participation rates for 10-14 years old versus UNESCO school enrolment ratios, IL 0 Bulletin of Labour Statistics, 2000-3.

Moehling, C.N. (1999), State child labor laws and the decline of child labor, E x plorations in E conomic H istory, 36, 72-106.

Psacharopoulos, G. (1997), Child labor versus educational attainment: Some evidence from Latin America, Journal of Population E conomics, 10, 377-386.

Ranjan, P. (1999), An economic analysis of child labor, E conomics L etters, 64, 99-105.

Ranjan, P. (2001), Credit constraints and the phenomenon of child labor, Journal of D evelopment E conomics, 64, 81-102.

Rodrik, D . (1996): Labor standards in international trade: do they matter and what do we do about them?, in: Lawrence, R.Z.; D. Rodrik; J. Whalley: E merging agenda for global trade: high stakes for developing countries. Policy essays no. 20, Overseas D evelopment Council, Washington.

Rodrik, D. (1999), Democracies pay higher wages, Quarterly Journal of E conomics, 64, 707-738.

Strang, D., P.M.Y . Chang (1993), The International Labor Organization and the welfare state, Institutional effects on national welfare spending, 196080, International O rganization, 47, 235-262.

Swepston, L. (1982), Child labour: Its regulation by ILO standards and national legislation, International L abour Review, 121, 577-593.

Swepston, L. (1997), Supervision of ILO standards, International Journal of Comparative L abour L aw and Industrial Relations, 13, 327-344.

Vaessen, M., M. Thiam, T. Lê (2003), D emographic and health surveys, Ms., forthcoming in: United Nations Statistical Division (ed.), H ousehold Surveys in Developing and Transition Countries, Part II: Case studies, http:/ / unstats.un.org/ unsd/ HHsurveys/ .

Weichselbaumer, D .; R. Winter-Ebmer (2003), The effects of competition and equal treatment laws on the gender wage, IZA D iscussion Paper No. 822, July. 


\section{Table 1: ILO Conventions on Minimum Age (except manitime sector) ${ }^{\mathrm{a}}$}

\begin{tabular}{|c|c|c|c|c|}
\hline No. & Title & $\begin{array}{l}\text { Year of } \\
\text { Adoptio } \\
\text { n }\end{array}$ & $\begin{array}{l}\text { Ratificatio } \\
\text { ns (1990) }\end{array}$ & Main Provisions \\
\hline 5 & Minimum Age (Industry) & 1919 & 69 & $\begin{array}{l}\text { Forbids employment of children under } 14 \text { in industrial undertakings other } \\
\text { than family businesses. }\end{array}$ \\
\hline 10 & Minimum Age (Agriculture) & 1921 & 51 & $\begin{array}{l}\text { Forbids employment of children under } 14 \text { in agriculture within the hours } \\
\text { of school attendance. Any other employment is not to prejudice school } \\
\text { attendance. }\end{array}$ \\
\hline 33 & $\begin{array}{l}\text { Minimum Age (Non-Industrial } \\
\text { Employment) }\end{array}$ & 1932 & 25 & $\begin{array}{l}\text { Forbids employment of children under } 14 \text { in sectors not covered by C5 } \\
\text { and C10, except for light work of children above } 12 \text { under certain } \\
\text { conditions. }\end{array}$ \\
\hline 59 & Minimum Age (Industry) (Revised) & 1937 & 35 & $\begin{array}{l}\text { Forbids employment of children under } 15 \text { in industrial undertakings other } \\
\text { than family businesses. }\end{array}$ \\
\hline 60 & $\begin{array}{l}\text { Minimum Age (Non-Industrial } \\
\text { Employment) (Revised) }\end{array}$ & 1937 & 11 & $\begin{array}{l}\text { Forbids employment of children under } 15 \text { in sectors not covered by C5 } \\
\text { and C10, except for light work of children above } 13 \text { under certain } \\
\text { conditions. }\end{array}$ \\
\hline 123 & Minimum Age (Underground Work) & 1965 & 38 & $\begin{array}{l}\text { Forbids employment in mines of persons below an age not less than } 16 \\
\text { but otherwise specified by the member state. Some measures for labour } \\
\text { inspection. }\end{array}$ \\
\hline 138 & Minimum Age & 1973 & 39 & $\begin{array}{l}\text { Obliges ratifying states to provide a minimum age for work that } \\
\text { corresponds to the end of compulsory schooling and is not below } 15 \\
\text { years. Insufficiently developed member states may initially specify a } \\
\text { minimum age of } 14 \text { years. Minimum age for hazardous work is } 18 \text { (initially, } \\
\text { 16) years and for light work } 13 \text { (initially, 12) years. Applies to all sectors, } \\
\text { though exceptions may be given. }\end{array}$ \\
\hline 182 & Worst Forms of Child Labour & 1999 & na & $\begin{array}{l}\text { Defines worst forms of child labour. Prohibits employment of persons } \\
\text { under } 18 \text { years in these forms of employment. Requires states to introduce } \\
\text { measures for monitoring. }\end{array}$ \\
\hline
\end{tabular}


Table 2: Activity rates and enrolment: comparisons between ratifiers and non-ratifiers

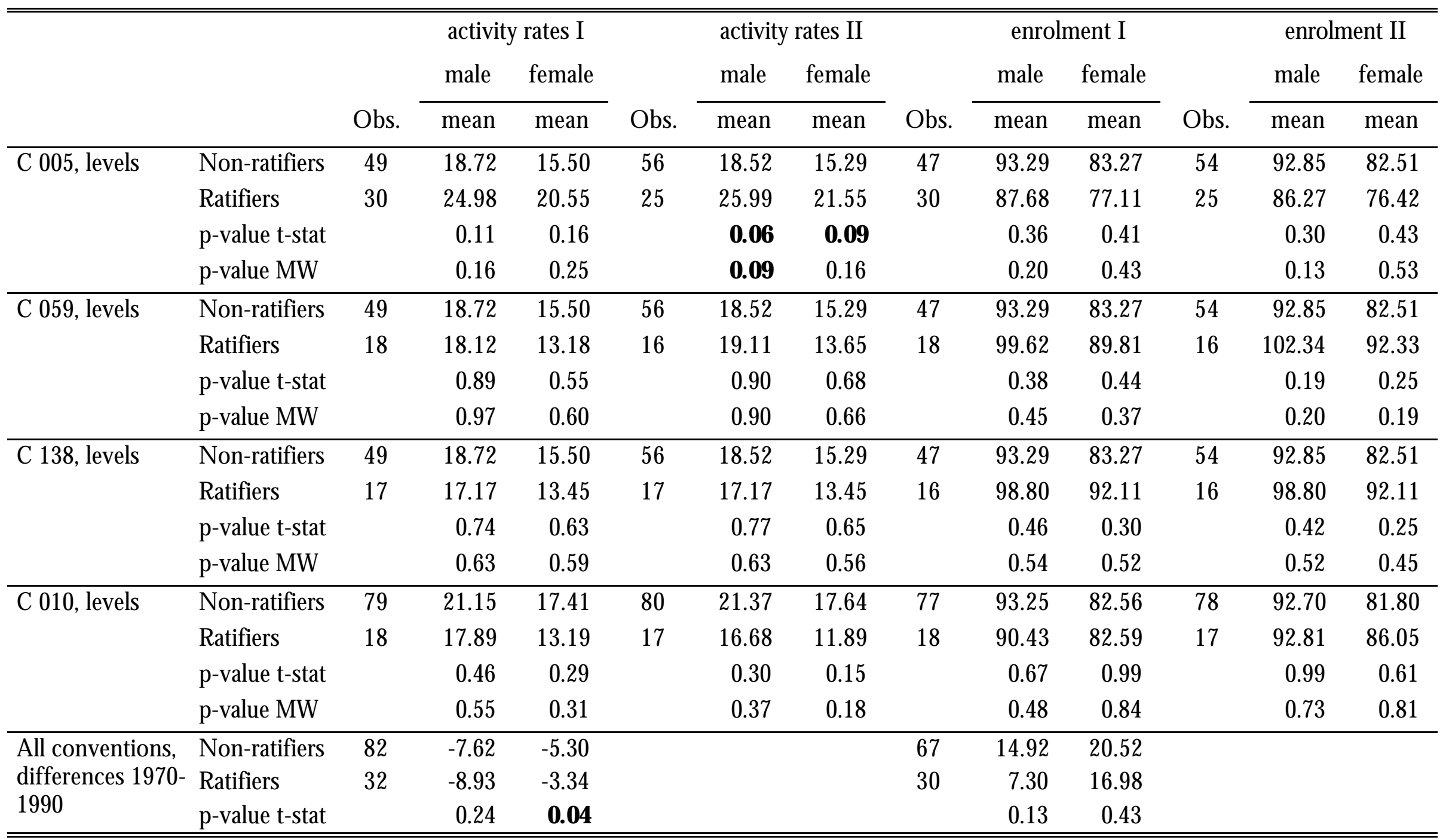

Activity rates and enrolment I and II: not accounting and accounting for compliance, respectively, as described in the text. MW p-values are from Mann-Whitney tests for equal distributions. Test statistics significant at the ten per cent level indicated by bold type. 
Table 3: Differences in Differences: 17 African countries

\begin{tabular}{lccc}
\hline \hline & Ratifiers & Non-Ratifiers & Difference \\
\hline $\begin{array}{l}\text { Treatment: Aged 13 } \\
\text { (obs.) }\end{array}$ & 0.569 & 0.605 & -0.035 \\
Control 1: Aged 14 & $(6484)$ & $(10799)$ & \\
(obs.) & 0.562 & 0.597 & -0.036 \\
\hline DD, no covariates & $(5086)$ & $(9858)$ & \\
(p-value, linear) & & & 0.000 \\
[p-value, probit] & & & $(0.989)$ \\
DD, with covariates & & & {$[0.997]$} \\
(p-value, linear) & & & 0.011 \\
[p-value, probit] & & 0.604 & $(0.490)$ \\
\hline Treatment: Aged 13 & 0.579 & $(10799)$ & -0.025 \\
(obs.) & $(6484)$ & 0.505 & \\
Control 2: Aged & 0.486 & $(9047)$ & -0.019 \\
14/ 15 (obs.) & $(4730)$ & & \\
\hline DD, no covariates & & & -0.006 \\
(p-value, linear) & & $0.674)$ \\
[p-value, probit] & & $0.645]$ \\
DD, with covariates & & & -0.021 \\
(p-value, linear) & & $0.177)$ \\
[p-value, probit] & & $0.168]$ \\
\hline \hline
\end{tabular}

Weighted data using survey weighting factors and ensuring equal weights across countries. P-values are based on robust standard errors from OLS or probit. 
Table 4: Differences in Differences, single countries over time

\begin{tabular}{|c|c|c|c|c|}
\hline Country & Age & First peniod & Second period & Difference \\
\hline \multirow[t]{2}{*}{ Bolivia } & $\begin{array}{l}13 \text { years } \\
\text { (obs.) } \\
14 \text { years } \\
\text { (obs.) } \\
\end{array}$ & $\begin{array}{c}0.842 \\
(1152) \\
0.768 \\
(1100) \\
\end{array}$ & $\begin{array}{c}0.895 \\
(1258) \\
0.841 \\
(1368) \\
\end{array}$ & $\begin{array}{l}0.054 \\
0.073\end{array}$ \\
\hline & $\begin{array}{l}\text { DD, no covariates } \\
\text { (p-value, linear) } \\
\text { [p-value, probit] } \\
\text { DD, with covariates } \\
\text { (p-value, linear) } \\
\text { [p-value, probit] }\end{array}$ & & & $\begin{array}{l}-0.019 \\
(0.408) \\
{[0.911]} \\
-0.013 \\
(0.552) \\
{[0.712]} \\
\end{array}$ \\
\hline \multirow[t]{2}{*}{ Egypt } & $\begin{array}{l}13 \text { years } \\
\text { (obs) } \\
14 \text { years } \\
\text { (obs) } \\
\end{array}$ & $\begin{array}{r}0.728 \\
(2257) \\
0.698 \\
(2116) \\
\end{array}$ & $\begin{array}{l}0.807 \\
(2313) \\
0.778 \\
(2283) \\
\end{array}$ & $\begin{array}{l}0.079 \\
0.080\end{array}$ \\
\hline & $\begin{array}{l}\text { DD, no covariates } \\
\text { (p-value, linear) } \\
\text { [p-value, probit] } \\
\text { DD, with covariates } \\
\text { (p-value, linear) } \\
\text { [p-value, probit] }\end{array}$ & & & $\begin{array}{c}-0.001 \\
(0.972) \\
{[0.830]} \\
0.011 \\
(0.575) \\
{[0.469]} \\
\end{array}$ \\
\hline \multirow[t]{2}{*}{ Nepal } & $\begin{array}{l}13 \text { years } \\
\text { (obs) } \\
14 \text { years } \\
\text { (obs) } \\
\end{array}$ & $\begin{array}{r}0.613 \\
(1024) \\
0.613 \\
(1086) \\
\end{array}$ & $\begin{array}{c}0.721 \\
(1145) \\
0.675 \\
(1116) \\
\end{array}$ & $\begin{array}{l}0.108 \\
0.063\end{array}$ \\
\hline & $\begin{array}{l}\text { DD, no covariates } \\
\text { (p-value, linear) } \\
\text { [p-value, probit] } \\
\text { DD, with covariates } \\
\text { (p-value, linear) } \\
\text { [p-value, probit] }\end{array}$ & & & $\begin{array}{c}0.045 \\
(0.142) \\
{[0.122]} \\
\mathbf{0 . 0 5 7} \\
(0.046) \\
{[0.030]} \\
\end{array}$ \\
\hline \multirow[t]{2}{*}{ Tanzania } & $\begin{array}{l}13 \text { years } \\
\text { (obs) } \\
14 \text { years } \\
\text { (obs) } \\
\end{array}$ & $\begin{array}{r}0.785 \\
(1012) \\
0.775 \\
(1048) \\
\end{array}$ & $\begin{array}{l}0.709 \\
(561) \\
0.696 \\
(429) \\
\end{array}$ & $\begin{array}{l}-0.076 \\
-0.079\end{array}$ \\
\hline & $\begin{array}{l}\text { DD, no covariates } \\
\text { (p-value, linear) } \\
\text { [p-value, probit] } \\
\text { DD, with covariates } \\
\text { (p-value, linear) } \\
\text { [p-value, probit] }\end{array}$ & & & $\begin{array}{c}0.002 \\
(0.956) \\
{[0.986]} \\
0.025 \\
(0.564) \\
{[0.753]}\end{array}$ \\
\hline
\end{tabular}

Weighted data using survey weights. P-values are based on robust standard errors from O LS or probit. Effects significant at the five per cent level printed in bold type. 
Table 5: Summary of results for the effect of ratification

\begin{tabular}{llll}
\hline \hline \multicolumn{1}{c}{ Bolivia } & \multicolumn{1}{c}{ Egypt } & \multicolumn{1}{c}{ N epal } & \multicolumn{1}{c}{ Tanzania } \\
\hline No significant effect & No significant effect & Significantly positive & Ratification did not \\
found. Increase in & found. Improvements & effect found, but & prevent decline in \\
school attendance in & in school attendance & unclear whether this is & schooling among \\
both age groups & mainly driven by & due to ratification of & children protected by \\
means that D D & covariates. & Convention No. 138 & Convention No. 138. \\
estimator may suffer & & or Basic and Primary & \\
from downward bias if & & Education Project. & \\
children aged 14 are & & & \\
indirectly affected. & & & \\
\hline \hline
\end{tabular}


Figure 1. Distribution of activity rates and gross enrolment ratios, 1990
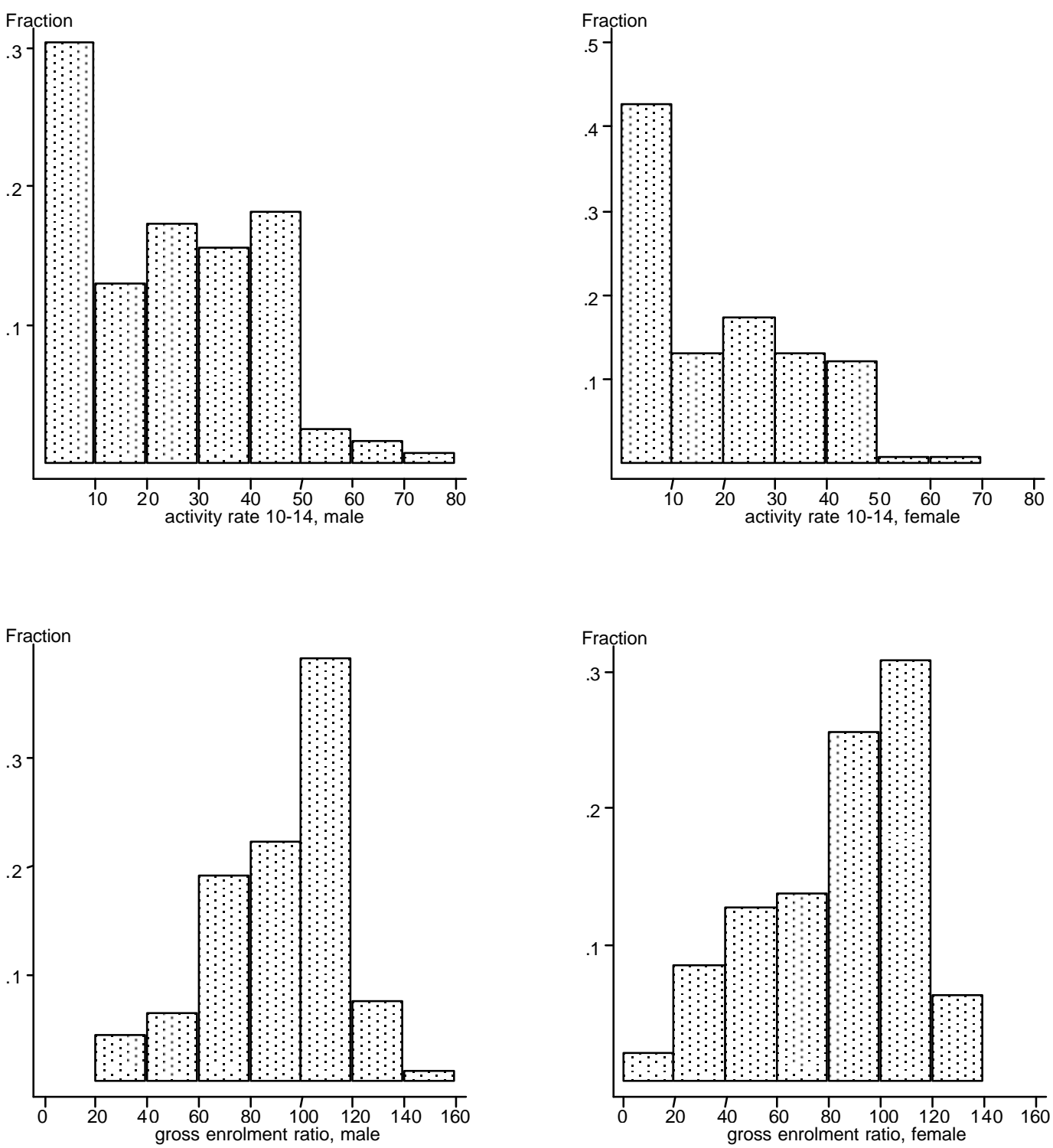


\section{Appendix}

\section{Table A1: Data description}

\begin{tabular}{|c|c|c|c|c|c|c|}
\hline & $\begin{array}{c}\text { Ratification } \\
\text { date }\end{array}$ & $\begin{array}{c}\text { Start of } \\
\text { school year }\end{array}$ & $\begin{array}{c}\text { Type of } \\
\text { first survey }\end{array}$ & $\begin{array}{l}\text { Date of } \\
\text { first survey }\end{array}$ & $\begin{array}{l}\text { Type of } \\
\text { second } \\
\text { survey }\end{array}$ & $\begin{array}{l}\text { Date of } \\
\text { second } \\
\text { survey }\end{array}$ \\
\hline \multicolumn{7}{|c|}{ Countries with two D H S surveys used in the analysis } \\
\hline Bolivia & June 1996 & February & DHS III & $\begin{array}{c}11 / 93 \text { to } \\
06 / 94\end{array}$ & DHS III & $\begin{array}{c}03 / 98 \text { to } \\
09 / 98\end{array}$ \\
\hline Egypt & June 1999 & September & DHS III & $\begin{array}{c}10 / 95 \text { to } \\
02 / 96\end{array}$ & DHS + & $\begin{array}{l}02 / 2000 \text { to } \\
04 / 2000\end{array}$ \\
\hline N epal & May 1997 & April & D HS III & $\begin{array}{c}10 / 95 \text { to } \\
02 / 96\end{array}$ & DHS + & $\begin{array}{l}10 / 00 \text { to } \\
03 / 01\end{array}$ \\
\hline Tanzania & $\begin{array}{c}\text { D ecember } \\
1998 \\
\end{array}$ & January & D HS III & $\begin{array}{c}07 / 96 \text { to } \\
11 / 96\end{array}$ & DHS III & $\begin{array}{c}09 / 99 \text { to } \\
11 / 99\end{array}$ \\
\hline \multicolumn{7}{|c|}{ C ountries with one D H S survey used in the analysis: ratified at time of survey } \\
\hline Malawi & $\begin{array}{c}\text { November } \\
1999\end{array}$ & January & DHS + & $\begin{array}{c}07 / 00 \text { to } \\
11 / 00\end{array}$ & & \\
\hline Niger & $\begin{array}{c}\text { D ecember } \\
1978\end{array}$ & October & DHS III & $\begin{array}{c}01 / 98 \text { to } \\
06 / 98\end{array}$ & & \\
\hline Rwanda & April 1981 & September & DHS + & $\begin{array}{c}07 / 00 \text { to } \\
11 / 00\end{array}$ & & \\
\hline Togo & $\begin{array}{l}\text { March } \\
1984\end{array}$ & October & D HS III & $\begin{array}{c}02 / 98 \text { to } \\
05 / 98\end{array}$ & & \\
\hline \multicolumn{7}{|c|}{ C ountries with one D H S survey used in the analysis: not ratified at time of survey } \\
\hline Cameroon & $\begin{array}{c}\text { August } \\
2001\end{array}$ & September & DHS III & $\begin{array}{c}02 / 98 \text { to } \\
06 / 98\end{array}$ & & \\
\hline $\begin{array}{l}\text { Centr. African } \\
\text { Republic }\end{array}$ & June 2000 & September & DHS III & $\begin{array}{c}9 / 94 \text { to } \\
3 / 95\end{array}$ & & \\
\hline Chad & - & August & DHS III & $\begin{array}{c}12 / 96 \text { to } \\
06 / 97\end{array}$ & & \\
\hline Côte d'Ivoire & $\begin{array}{l}\text { February } \\
2003\end{array}$ & O ctober & D HS III & $\begin{array}{c}09 / 98 \text { to } \\
03 / 99\end{array}$ & & \\
\hline Gabon & - & O ctober & $\mathrm{DHS}+$ & $\begin{array}{c}07 / 2000 \text { to } \\
01 / 2001\end{array}$ & & \\
\hline Ghana & - & October & DHS + & $\begin{array}{c}11 / 98 \text { to } \\
02 / 99\end{array}$ & & \\
\hline Guinea & June 2003 & not available & DHS + & $\begin{array}{c}05 / 99 \text { to } \\
07 / 99\end{array}$ & & \\
\hline Madagascar & May 2000 & September & DHS + & $\begin{array}{l}09 / 97 \text { to } \\
12 / 97\end{array}$ & & \\
\hline Mali & $\begin{array}{l}\text { March } \\
2002\end{array}$ & November & DHS + & $\begin{array}{c}\text { 01/ } 2001 \text { to } \\
05 / 2001\end{array}$ & & \\
\hline Mozambique & June 2003 & February & D HS III & $\begin{array}{c}03 / 97 \text { to } \\
06 / 97\end{array}$ & & \\
\hline Nigeria & $\begin{array}{l}\text { October } \\
2002\end{array}$ & January & DHS + & $\begin{array}{c}03 / 99 \text { to } \\
05 / 99\end{array}$ & & \\
\hline Uganda & $\begin{array}{l}\text { March } \\
2003\end{array}$ & February & D HS III & $\begin{array}{c}03 / 95 \text { to } \\
08 / 95\end{array}$ & & \\
\hline
\end{tabular}


Table A2: Probit estimation, 17 African countries

\begin{tabular}{|c|c|c|c|}
\hline & \multicolumn{3}{|c|}{ Coefficients common to all countries } \\
\hline Aged 13 & \multicolumn{3}{|c|}{$\begin{array}{c}\mathbf{0 . 1 2} \\
(3.96)\end{array}$} \\
\hline DD & \multicolumn{3}{|c|}{$\begin{array}{c}0.02 \\
(0.39)\end{array}$} \\
\hline \multirow[t]{2}{*}{ Country dummies } & \multicolumn{3}{|c|}{ YES } \\
\hline & Average & Minimum & Maximum \\
\hline Usual resident & $\begin{array}{c}0.17 \\
(1.72)\end{array}$ & $\begin{array}{c}\mathbf{- 5 . 4 4} \\
(-12.30)\end{array}$ & $\begin{array}{c}\mathbf{1 . 7 9} \\
(3.47)\end{array}$ \\
\hline Female & $\begin{array}{c}-\mathbf{0 . 4 0} \\
(-19.19)\end{array}$ & $\begin{array}{l}-\mathbf{0 . 7 5} \\
(-9.35)\end{array}$ & $\begin{array}{l}-0.03 \\
(-0.26)\end{array}$ \\
\hline $\begin{array}{l}\text { Female Household } \\
\text { Head }\end{array}$ & $\begin{array}{c}\mathbf{0 . 1 7} \\
(6.31)\end{array}$ & $\begin{array}{c}-\mathbf{- 0 . 2 5} \\
(-2.13)\end{array}$ & $\begin{array}{c}\mathbf{0 . 8 4} \\
(6.17)\end{array}$ \\
\hline Members under 6 & $\begin{array}{r}\mathbf{- 0 . 0 9} \\
(-6.91)\end{array}$ & $\begin{array}{r}-0.21 \\
(-3.14)\end{array}$ & $\begin{array}{c}0.01 \\
(0.30)\end{array}$ \\
\hline Members under 14 & $\begin{array}{c}-0.01 \\
(-0.68)\end{array}$ & $\begin{array}{c}-\mathbf{- 0 . 1 2} \\
(-2.67)\end{array}$ & $\begin{array}{c}0.07 \\
(1.38)\end{array}$ \\
\hline Members under 18 & $\begin{array}{c}\mathbf{0 . 0 5} \\
(4.48)\end{array}$ & $\begin{array}{c}-0.03 \\
(-0.79)\end{array}$ & $\begin{array}{c}\mathbf{0 . 1 4} \\
(3.52)\end{array}$ \\
\hline $\begin{array}{l}\text { Household head: } \\
\text { primary education }\end{array}$ & $\begin{array}{c}\mathbf{0 . 4 1} \\
(15.00)\end{array}$ & $\begin{array}{c}0.05 \\
(0.78)\end{array}$ & $\begin{array}{r}\mathbf{0 . 9 8} \\
(9.19)\end{array}$ \\
\hline $\begin{array}{l}\text { Household head: } \\
\text { secondary education }\end{array}$ & $\begin{array}{c}\mathbf{0 . 6 2} \\
(16.94)\end{array}$ & $\begin{array}{c}0.04 \\
(0.36)\end{array}$ & $\begin{array}{r}\mathbf{1 . 2 4} \\
(8.54)\end{array}$ \\
\hline Household wealth & $\begin{array}{c}\mathbf{0 . 1 1} \\
(13.06)\end{array}$ & $\begin{array}{l}-0.07 \\
(-1.84)\end{array}$ & $\begin{array}{r}\mathbf{0 . 3 2} \\
(9.06)\end{array}$ \\
\hline Rural area & $\begin{array}{c}-\mathbf{- 0 . 1 0} \\
(-3.38)\end{array}$ & $\begin{array}{c}-\mathbf{0 . 7 8} \\
(-7.14)\end{array}$ & $\begin{array}{r}\mathbf{0 . 6 6} \\
(4.09)\end{array}$ \\
\hline $\begin{array}{l}\text { Number of } \\
\text { observations }\end{array}$ & & 31091 & \\
\hline LL initial & & -20955.4 & \\
\hline LL final & & -15959.5 & \\
\hline
\end{tabular}

Asymptotic t-statistics in parentheses. Standard errors estimated robustly. Average coefficients are the coefficients obtained from including the independent variable linearly, with the 16 coefficients of the interaction terms constrained to sum to unity. Standard errors of minimum (maximum) coefficients are from a regression with 17 interaction terms. Coefficients significant at the five per cent level printed in bold type. 
Table A3: Probit estimation, single countries over time

\begin{tabular}{|c|c|c|c|c|}
\hline & Bolivia & Egypt & Nepal & Tanzania \\
\hline Age 13 & $\begin{array}{c}\mathbf{0 . 2 8} \\
(3.35)\end{array}$ & $\begin{array}{c}0.06 \\
(0.97)\end{array}$ & $\begin{array}{c}0.05 \\
(0.73)\end{array}$ & $\begin{array}{l}-0.03 \\
(0.35)\end{array}$ \\
\hline Usual resident & $\begin{array}{c}0.18 \\
(1.03)\end{array}$ & $\begin{array}{c}0.24 \\
(1.06)\end{array}$ & $\begin{array}{c}\mathbf{0 . 2 8} \\
(2.05)\end{array}$ & $\begin{array}{c}\mathbf{0 . 8 8} \\
(4.69)\end{array}$ \\
\hline Female & $\begin{array}{l}-\mathbf{0 . 3 7} \\
(-7.08)\end{array}$ & $\begin{array}{c}-0.32 \\
(-8.78)\end{array}$ & $\begin{array}{r}\mathbf{- 0 . 6 3} \\
(-14.03)\end{array}$ & $\begin{array}{l}-0.08 \\
(-1.27)\end{array}$ \\
\hline $\begin{array}{l}\text { Female Household } \\
\text { Head }\end{array}$ & $\begin{array}{c}0.07 \\
(0.95)\end{array}$ & $\begin{array}{c}0.05 \\
(0.87)\end{array}$ & $\begin{array}{r}\mathbf{0 . 3 1} \\
(4.23)\end{array}$ & $\begin{array}{r}\mathbf{0 . 2 1} \\
(2.72)\end{array}$ \\
\hline Mother alive & $\begin{array}{c}\mathbf{0 . 3 7} \\
(3.18)\end{array}$ & & & $\begin{array}{l}\mathbf{0 . 2 9} \\
(2.78)\end{array}$ \\
\hline Father alive & & & & $\begin{array}{c}0.07 \\
(0.82)\end{array}$ \\
\hline Members under 6 & $\begin{array}{c}\mathbf{- 0 . 1 9} \\
(-4.57)\end{array}$ & $\begin{array}{l}\mathbf{- 0 . 0 8} \\
(-3.23)\end{array}$ & $\begin{array}{c}\mathbf{- 0 . 2 0} \\
(-6.32)\end{array}$ & $\begin{array}{c}-\mathbf{0 . 1 3} \\
(-3.21)\end{array}$ \\
\hline Members under 14 & $\begin{array}{c}0.04 \\
(0.99)\end{array}$ & $\begin{array}{c}\mathbf{0 . 0 7} \\
(2.39)\end{array}$ & $\begin{array}{c}-0.04 \\
(-1.09)\end{array}$ & $\begin{array}{c}0.08 \\
(1.74)\end{array}$ \\
\hline Members under 18 & $\begin{array}{c}-0.05 \\
(-1.25)\end{array}$ & $\begin{array}{c}\mathbf{- 0 . 0 8} \\
(-3.66)\end{array}$ & $\begin{array}{c}\mathbf{0 . 0 7} \\
(2.09)\end{array}$ & $\begin{array}{l}-0.02 \\
(-0.41)\end{array}$ \\
\hline $\begin{array}{l}\text { Household head: } \\
\text { primary education }\end{array}$ & $\begin{array}{c}\mathbf{0 . 2 9} \\
(3.85)\end{array}$ & $\begin{array}{r}\mathbf{0 . 3 9} \\
(9.36)\end{array}$ & $\begin{array}{c}\mathbf{0 . 2 7} \\
(5.00)\end{array}$ & $\begin{array}{c}\mathbf{0 . 4 9} \\
(7.61)\end{array}$ \\
\hline $\begin{array}{l}\text { Household head: } \\
\text { secondary education }\end{array}$ & $\begin{array}{r}\mathbf{0 . 3 1} \\
(3.56)\end{array}$ & $\begin{array}{r}\mathbf{0 . 9 5} \\
(16.86)\end{array}$ & $\begin{array}{l}\mathbf{0 . 5 7} \\
(8.45)\end{array}$ & $\begin{array}{r}\mathbf{0 . 5 1} \\
(3.52)\end{array}$ \\
\hline Household wealth & $\begin{array}{c}\mathbf{0 . 1 3} \\
(6.63)\end{array}$ & $\begin{array}{r}\mathbf{0 . 2 2} \\
(16.93)\end{array}$ & $\begin{array}{c}\mathbf{0 . 1 8} \\
(6.96)\end{array}$ & $\begin{array}{c}\mathbf{0 . 0 7} \\
(2.33)\end{array}$ \\
\hline Rural area & $\begin{array}{l}-\mathbf{0 . 5 2} \\
(-7.24)\end{array}$ & $\begin{array}{c}0.04 \\
(0.85)\end{array}$ & $\begin{array}{c}0.09 \\
(0.91)\end{array}$ & $\begin{array}{c}0.04 \\
(0.43)\end{array}$ \\
\hline $\begin{array}{l}\text { D ummy for second } \\
\text { period }\end{array}$ & $\begin{array}{c}\mathbf{0 . 2 2} \\
(3.07)\end{array}$ & $\begin{array}{c}\mathbf{0 . 1 2} \\
(2.39)\end{array}$ & $\begin{array}{c}0.06 \\
(0.98)\end{array}$ & $\begin{array}{c}\mathbf{- 0 . 2 7} \\
(-2.70)\end{array}$ \\
\hline DD & $\begin{array}{c}0.04 \\
(0.37)\end{array}$ & $\begin{array}{c}0.05 \\
(0.72)\end{array}$ & $\begin{array}{c}\mathbf{0 . 1 9} \\
(2.17) \\
\end{array}$ & $\begin{array}{c}0.04 \\
(0.31) \\
\end{array}$ \\
\hline $\begin{array}{l}\text { Number of } \\
\text { observations }\end{array}$ & 4773 & 8965 & 4355 & 2999 \\
\hline LL initial & -2099.4 & -4994.8 & -2800.7 & -2078.7 \\
\hline LL final & -1742.3 & -4165.8 & -2452.6 & -1570.4 \\
\hline
\end{tabular}

Asymptotic t-statistics in parentheses. Standard errors estimated robustly. Coefficients significant at the five per cent level printed in bold type. 
Table A4: Institutions influencing child labour

\begin{tabular}{|c|c|c|c|c|}
\hline & Bolivia & Egypt & Nepal & Tanzania \\
\hline $\begin{array}{l}\text { Minimum age for } \\
\text { employment }\end{array}$ & $\begin{array}{l}\text { Prohibition of } \\
\text { work under } 14 \\
\text { for all } \\
\text { employment, but } \\
\text { apprenticeship } \\
\text { for children 12- } \\
14 \text { admissible }\end{array}$ & $\begin{array}{l}\text { Prior to 1996: } 12 \\
\text { years. Under the } \\
\text { Child Law } \\
\text { adopted in March } \\
\text { 1996, the } \\
\text { minimum age for } \\
\text { admission to } \\
\text { employment is } 14 \\
\text { years but allows } \\
\text { children between } \\
\text { the ages of twelve } \\
\text { and fourteen to } \\
\text { receive vocational } \\
\text { training . }\end{array}$ & $\begin{array}{l}\text { Children's Act of } \\
1992 \text { prohibits } \\
\text { the employment } \\
\text { of children under } \\
14 \text { years }\end{array}$ & $\begin{array}{l}\text { Employment } \\
\text { ordinance sets } \\
\text { minimum age at } \\
12 \text { years, but } 15 \\
\text { years in specific } \\
\text { sectors }\end{array}$ \\
\hline $\begin{array}{l}\text { Compulsory } \\
\text { schooling }\end{array}$ & $\begin{array}{l}\text { Compulsory for a } \\
\text { minimum of } 8 \\
\text { years for children } \\
\text { aged } 6 \text { to } 14\end{array}$ & $\begin{array}{l}\text { Compulsory } \\
\text { schooling } \\
\text { increased from } 8 \\
\text { to } 9 \text { years in } 1999\end{array}$ & $\begin{array}{l}\text { Legislation exists } \\
\text { only in a } \\
\text { comparatively } \\
\text { small number of } \\
\text { districts }\end{array}$ & $\begin{array}{l}\text { Compulsory for } \\
\text { children between } \\
\text { the ages of } 7 \text { and } \\
13\end{array}$ \\
\hline $\begin{array}{l}\text { Participation in } \\
\text { IPEC }\end{array}$ & from 1996 & from 1996 & from 1994 & from 1994 \\
\hline $\begin{array}{l}\text { World Bank } \\
\text { programmes } \\
\text { relating to } \\
\text { education }\end{array}$ & $\begin{array}{l}\text { Education } \\
\text { Reform Project, } \\
\text { 1994-2004 }\end{array}$ & $\begin{array}{l}\text { Education } \\
\text { Enhancement } \\
\text { Program Project } \\
\text { (1996-2004), } \\
\text { Basic Education } \\
\text { Improvement } \\
\text { Project (1993- } \\
\text { 2003) }\end{array}$ & $\begin{array}{l}\text { Nepal Basic and } \\
\text { Primary } \\
\text { Education } \\
\text { Project, round } 1 \\
(1992-99), \text { round } \\
2 \text { (1999-2004) }\end{array}$ & $\begin{array}{l}\text { Education } \\
\text { Planning and } \\
\text { Rehabilitation } \\
\text { Project, 1990-97 }\end{array}$ \\
\hline $\begin{array}{l}\text { O bservations by } \\
\text { the CEACR from } \\
1990\end{array}$ & $\begin{array}{l}\text { Convention No. } \\
5(1990,1992, \\
\text { 1994, 1995, 1996, } \\
\text { 1997) } \\
\text { Convention No. } \\
138 \text { (2003) }\end{array}$ & & & \\
\hline
\end{tabular}

Sources: ILO (1991), NATLEX data base, the World Bank, and information from governments and NG Os published on the internet. 
Figure A1: Construction of the comparison group, Central African Republic

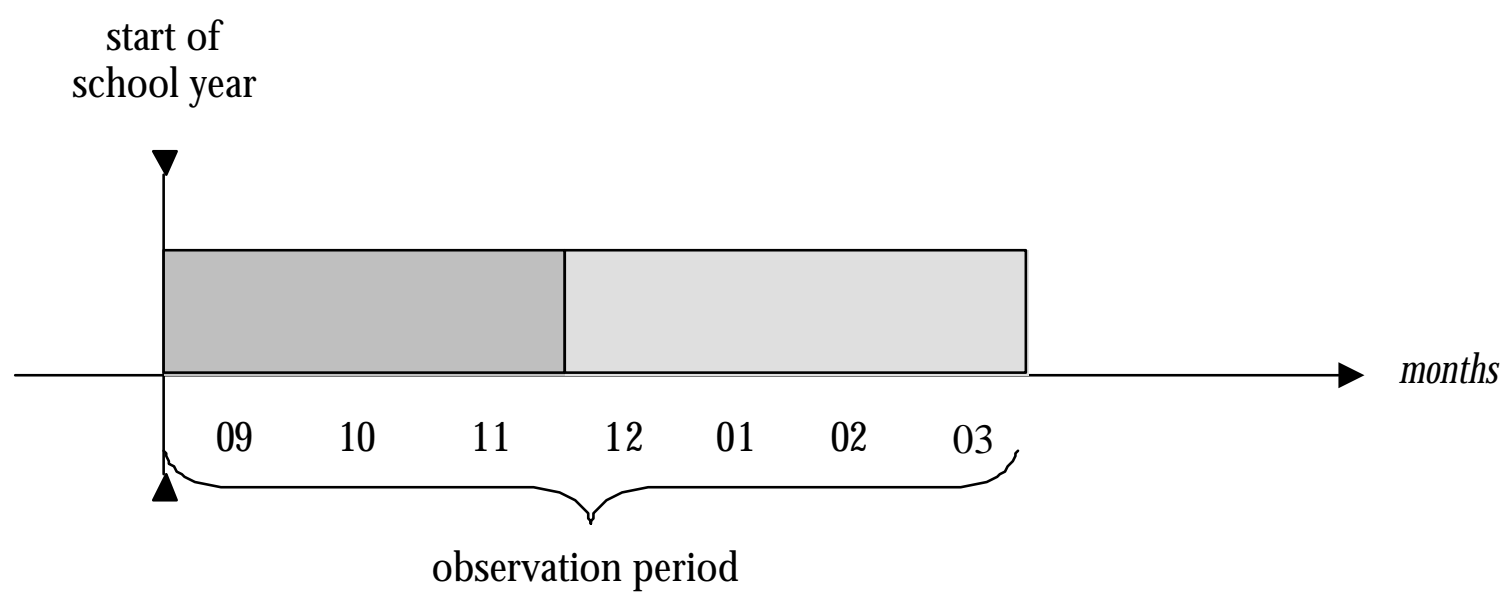

aged 14

$\square$ aged 15 